\title{
Pemanfaatan Blog Pribadi Di Instagram Sebagai Media Komunikasi Parenting (Studi Deskriptif Kualitatif Akun Instagram @annisast)
}

\author{
Gan Gan Giantika \\ Universitas Bina Sarana Informatika \\ e-mail: gan.ggt@bsi.ac.id
}

Cara Sitasi: Giantika, G. G. (2019). Pemanfaatan Blog Pribadi Di Instagram Sebagai Media Komunikasi Parenting ( Studi Deskriptif Kualitatif Akun Instagram @ annisast ). Jurnal Komunikasi, 10(1), 1-9.

\begin{abstract}
Instagram has become a popular social media, because everyone is also competing to populate themselves with their Instagram account, one of the personal blog accounts in the instragam account that @annisast uses its account as a communication medium that provides information and education to users of Instagram account other. The purpose of this research is to find out the utilization and process of utilizing personal blogs on Instagram as a parenting communication media. Research uses a qualitative research approach, a type of qualitative descriptive study research. The result of the research is the @annisast instagram account in his personal blogging, there is the use of instagram as a parenting communication media, one of which is in the image titled from upload both in terms of many followers who appreciate it, can be seen from the thanks for the tips and the discussion in the comment column, upload the uploaded photo namely everyday photos with children and images that match the theme of the tips discussed, the title of the photo in accordance with the parenting discussion, namely "Yasss ... ParentingHack" which states that succeeding in changing children's habits, the use of arobba signs (@) for some other users in order to access more about parenting information, geotagging use aims to find out the location about the parenting info discussed, follower likes for each photo upload range from 150-500 likes, popular (explore) by sharing the uploads through other links such as www. annisast.com d an www.orami.co.id.
\end{abstract}

Keywords: Instagram, qualitative descriptive, Parenting, @annisast.

\section{PENDAHULUAN}

Dengan pesatnya perkembangan new media, telah memberikan dampak terhadap situs-situs komunikasi, dari sekedar email dan chatting, menjadi media sosial atau jejaring sosial seperti Facebook, Twitter, Instagram, Path, Snapchat. Media sosial yang semakin marak di Indonesia, dapat memudahkan penggunanya dalam melakukan komunikasi. Media sosial berperan dalam aktifitas keseharian dalam bersosialisasi. Salah satu media sosial yang sedang banyak digunakan oleh pengguna gadget saat ini adalah Instagram. Internet, sosial media dan jejaring sosial memang membawa perubahan bagi dunia, tetapi tetap saja disamping dampak positif pasti diiringi dampak negatif terutama dalam hal pergaulan.

Munculnya situs-situs pertemanan (media sosial) yang kian digandrungi jutaan penduduk dunia ternyata juga mampu memicu pergeseran nilai-nilai sosial dalam masyarakat, khususnya remaja. Media sosial telah menjadi bagian dari pengalaman tumbuh dewasa untuk para remaja. (Griggs, 2009)
Di seluruh dunia, faktanya Instagram punya lebih dari 800 juta orang dengan kesibukan baru: berbagi foto, mulai dari menu makan malam hari ini, acara liburan keluarga hingga gambar selfie, baik yang pakai maupun yang tanpa gigi.

Banyak pengguna Instagram yang bertujuan untuk mengekspresikan kepribadiannya masing-masing melalui media sosial Instagram, salah satunya adalah untuk memenuhi kesenangan dan kepuasan dirinya melalui upload-an foto yang mereka lakukan. Dalam hal mengupload foto di Instagram dapat memberikan kebebasan berekspresi untuk memenuhi kepuasan tersendiri. Instagram salah satu sebuah aplikasi berbagi foto yang memungkinkan pengguna mengambil foto, menerapkan filter digital, dan membagikannya ke berbagai layanan jejaring sosial, termasuk milik Instagram sendiri. Instagram berdiri pada tahun 2010 dan didirikan oleh dua bersahabat Kevin Systrom dan Mike Krieger. Tujuan umum dari Instagram itu sendiri salah satunya yakni sebagai sarana kegemaran dari masing-masing individu yang ingin mempublikasikan kegiatan, barang, tempat atau 
pun dirinya sendiri kedalam bentuk foto. Hal tersebut menjadi menarik jika dikaitkan dengan perkembangan instagram pada saat ini. Di dalam instagram, dapat dikatakan sebagai ajang pamer atau yang lainnya.

Namun perkembangannya saat ini di Indonesia, Pengguna Instagram pasti sudah tidak asing dengan promosi barang yang ditawarkan melalui kolom komentar di sebuah post. Tidak jarang ditemui sebuah post foto bukannya berisi komentar tentang post tersebut, melainkan promosi barang oleh akun lain.

Instagram adalah salah satu media sosial dan jalur online terbesar saat ini, menggantikan popularitas Twitter, dengan jumlah user lebih dari 400 juta dan terus bertambah, serta pemakaian dalam urusan bisnis, branding, dan marketing yang makin lama makin populer. Indonesia sebagai salah satu negara dengan penduduk terbanyak mendukung semakin besarnya pengguna smartphone dan media sosial. Survei dari We Are Social tahun 2014 menemukan bahwa 32 persen pengguna media sosial memiliki akun Instagram. Selain itu, 74 persen pengguna smartphone menggunakan aplikasi media sosial di perangkatnya, dan 57 persen pengguna smartphone melakukan pembelian lewat ponselnya di tahun itu. Data tersebut berhasil menggambarkan bahwa potensi pasar untuk berjualan lewat media sosial teramat besar.

Salah satu kemungkinan yang jadi keunggulan Instagram adalah kemudahan yang ditawarkan. Dalam membuat sebuah katalog di Instagram, seperti membuat website sendiri. Hal yang dibutuhkan hanyalah smartphone dan jaringan internet. Sebenarnya, tidak alasan khusus mengapa Instagram menjadi media sosial yang cukup populer untuk berjualan. Sebab, selain Instagram, jejaring sosial lain juga digunakan sebagai media berjualan.

Bagaimana sebuah media sosial tidak lagi menjadi bagian dari strategi pemasaran, tapi berubah wujud menjadi mewujudkan suatu hobi yang dapat memberikan informasi, pengalaman dan penghasilan. Inilah yang terjadi di Instagram di Indonesia bukan hanya barang yang dipopularkan sekarang setiap orang juga berlomba-lomba untuk mempopularkan dirinya dengan akun instagram dengan mencirikhaskan portofolio dan hobi baik traveler, photography, kuliner, parenting dan lainya.

Salah satu akun blog pribadi di instragam yang memiliki bahasan yang khusus adalah akun @annisast merupakan salah satu parenting blogger Indonesia. sang pemilik akun juga sudah menghasilkan buku yang berjudul "susahnya Jadi Ibu". Pemilik akun semenjak memiliki anak sudah konsen terhadap parenting, sehingga akun instragramnya berisi mengenai seputar ibu dan anak, tips dan trik mengenai anak.
Beralih fungsinya setiap akun instagram memiliki tujuan masing-masing untuk memenuhi kebutuhan yang sama bagi para followernya. Hal ini dapat menjadi media informasi dan komunikasi netijen dalam memenuhi pengetahuannya dan interest pada suatu bidang mereka cenderung akan mengikuti akun tersebut.

Rumusan masalah dalam penelitian ini adalah "Bagaimana Pemanfaatan Blog Pribadi Di Instagram Sebagai Media Komunikasi Parenting Akun Instagram @annisast?

Sedangkan Tujuan dalam penelitian ini adalah:

1. Untuk mengetahui Pemanfaatan Blog Pribadi Di Instagram Sebagai Media Komunikasi Parenting.

2. Untuk mengetahui proses Pemanfaatan Blog Pribadi Di Instagram Sebagai Media Komunikasi Parenting.

Penelitian ini didukung oleh beberapa teori yaitu Komunikasi berasal dari bahasa Latin "communis" atau "common" dalam bahasa Inggris yang berarti sama. Berkomunikasi berarti kita sedang berusaha menyampaikan makna, "commonness" Atau dengan ungkapan lain, melalui komunikasi kita mencoba berbagai informasi, gagasan, atau sikap kita dengan partisipan lainnya. Istilah pertama (communis) adalah istilah yang paling sering sebagai asal usul komunikasi, yang merupakan akar dari kata-kata Latin lainnya yang mirip. Komunikasi menyarankan bahwa suatu pikiran, suatu makna, atau suatu pesan dianut secara sama. Oleh karena itu, komunikasi bergantung pada kemampuan kita untuk dapat memahami satu dengan yang lain.

Komunikasi adalah ilmu yang mempelajari usaha manusia dalam menyampaikan isi pernyataan kepada manusia lain. Objek ilmu komunikasi adalah usaha manusia dalam menyampaikan isi pernyataan kepada manusia lain. (Soehoet, 2003)

Sedangkan menurut forsadale Komunikasi adalah "commucation is the process by which a system is estabilished, maintained, and altered by means of shared signals that operate according to rules". (Mulyana, 2001)

Pendapat di atas memiliki pemahaman bahwa komunikasi merupakan proses dalam menyampaikan pesan dari orang kepada orang lainnya. Dalam proses menyampaikan pesan diperlukan adanya sepemahaman yang sama antara satu orang kepada orang lain.

Komunikasi sebagai sebuah proses memaknai yang dilakukan oleh seseorang (I) terhadap informasi, sikap, dan prilaku orang lain yang berbentuk pengetahuan, pembicaraan, gerak-gerik, atau sikap, perilaku atau perasaan-perasaan, sehingga seseorang 
membuat reaksi-reaksi terhadap informasi, sikap, dan prilaku tersebut berdasarkan pada pengalaman yang pernah dia alami. Dalam komunikasi ada tiga unsur penting yang selalu hadir dalam setiap komunikasi, yaitu sumber informasi (receiver), saluran (media), dan penerimaan (audience). Selain tiga unsur ini, yang terpenting dalam komunikasi adalah aktivitas memaknakan informasi yang disampaikan oleh sumber informasi yang disampaikan oleh audience terhadap informasi-informasi yang terimanya. Pemaknaan kepada informasi bersifat subjektif dan kontekstual. (Bungin, 2007)

Menurut Lasswell tentang komunikasi secara eksplisit dan kronologis menjelaskan tentang lima komponen yang terlibat dalam komunikasi, yaitu:

1. Siapa, yakni pelaku komunikasi pertama yang mempunyai inisiatif atau sumber.

2. Mengatakan apa, yakni isi informasi yang disampaikan.

3. Kepada siapa, yakni pelaku komunikasi lainnya yang dijadikan sasaran penerima.

4. Melalui saluran apa, yakni alat atau saluran penyampaian informasi.

5. Dengan akibat atau hasil apa, yakni hasil yang terjadi pada diri penerima. (Riswandi, 2009)

Gaya komunikasi (the communication style) diartikan sebagai seperangkat perilaku antar pribadi yang dapat digunakan dalam suatu situasi tertentu (a specialized set of intexpersonal behaviors that are used in a given situation). Masing-masing gaya komunikasi terdiri dari sekumpulan perilaku komunikasi yang dipakai untuk mendapatkan respon atau tanggapan tertentu dalam situasi tertentu pula. Kesesuaian dari satu gaya komunikasi yang digunakan, bergantung pada maksud dari pengirim (sender) dan harapan dari penerima (receiver). (Effendy, 2001)

Konsep itu berkaitan dengan struktur sosial antara pelaku, sebagian besar individu,atau organisasi, yang menunjukkan cara mereka terhubung melalui berbagai hubungan sosial seperti persahabatan, rekan kerja, atau pertukaran informasi.

Menurut Andreas Kaplan dan Michael Haenlein Media sosial ada dalam ada dalam berbagai bentuk yang berbeda, termasuk social network, forum internet, weblogs, social blogs, micro blogging, wikis, podcasts, gambar, video, rating, dan bookmark sosial. Menurut Kaplan dan Haenlein ada enam jenis media sosial: proyek kolaborasi (misalnya, wikipedia), blog dan microblogs (misalnya, twitter), komunitas konten (misalnya, youtube), situs jaringan sosial (misalnya facebook, instagram), virtual game (misalnya world of warcraft), dan virtual social (misalnya, second life). (Lesmana, 2012)

Media sosial adalah penerbitan online dan alat-alat komunikasi, situs, dan tujuan dari Web 2.0 yang berakar pada percakapan, keterlibatan, dan partisipasi. (Gunelius, 2011)

Definisi media sosial adalah media online partisipatif yang mempublikasikan berita, foto, video, dan podcast yang diumumkan melalui situs media sosial. Biasanya disertai dengan proses pemungutan suara untuk membuat media item menjadi populer. Media sosial dapat mengambil berbagai bentuk, termasuk forum internet, papan pesan, weblog, wiki, podcast, gambar dan video. Teknologi seperti blog, berbagi gambar, dinding posting, e-mail, instant messaging, music-sharing, pembuatan grup dan voice over IP. Beberapa Jenis aplikasi media sosial adalahBookmarking, Content Sharing, Wiki, Flikcr, Connecting, Creating-opinion, Blog. (Puntoadi, 2011)

Media sosial adalah sebuah media online, dengan para penggunanya bisa dengan mudah berpartisipasi, berbagi dan menciptakan isi meliputi

blog, jejaring sosial, wiki, forum dan dunia virtual. Blog, jejaring sosial dan Wiki merupakan bentuk media sosial yang paling umum digunakan oleh masyarakat di seluruh dunia.

Sosial media memiliki beberapa fungsi sebagai berikut :

1. Sosial media adalah media yang didesain untuk memperluas interaksi sosial manusia menggunakan internet dan teknologi web.

2. Sosial media berhasil mentransformasi praktik komunikasi searah media siaran dari satu institusi media ke banyak audience ("one to many") menjadi praktik komunikasi dialogis antar banyak audience ("many to many").

3. Sosial media mendukung demokratisasi pengetahuan dan informasi. Mentransformasi manusia dari pengguna isi pesan menjadi pembuat pesan itu sendiri. (Wijayanto, 2016)

Media sosial sebagai media komunikasi, persepsi masyarakat dapat dibentuk dengan media komunikasi dapat berbentuk media massa maupun online seperti halnya instagram sebagai media sosial. Media dapat membentuk pendapat umum dengan cara pemberitaan yang sensasional dan berkesinambungan. Hasil dari pemberitaan adalah pencitraan yang positif, karena media memiliki fungsi dalam pembentukan opini publik seperti yang diutarakan Alexis S. Tan adalah sebagai berikut:

1. Fungsi Memberi Informasi, mempela- jari ancaman dan peluang, memahami lingkungan, menguji kenyataan, meraih keputusan.

2. Fungsi Mendidik, media memperoleh pengetahuan dan keterampilan yang berguna memfungsikan dirinya secara efektif dalam masyarakatnya, mempe- lajari nilai, tingkah laku yang cocok agar diterima masyarakatnya. 
3. Fungsi Mempersuasi, media memberi keputusan, mengadopsi nilai, tingkah laku dan aturan yang cocok agar dite- rima dalam masyarakatnya.

4. Fungsi Menyenangkan, Memuaskan Kebutuhan Komunikan, Menggembi- rakan, mengendorkan urat syaraf, menghibur dan mengalihkan perhatian dari masalah yang dihadapi. (Nurudin, 2013)

Instagram adalah sebuah aplikasi untuk berbagi foto yang dapat dilihat oleh Follow- ers dari pengunggah foto tersebut dan dapat saling memberikan komentar antara sesama- nya. Nama Instagram sendiri berasal dari insta dan gram, "insta" yang berasal dari kata instant dan "gram" yang berasal dari telegram, dapat disimpulkan dari namanya yang berarti menginformasikan atau membagikan foto kepada orang lain dengan cepat. Salah satu yang unik dari Instagram adalah foto yang berbentuk per- segi, ini terlihat seperti kamera Polaroid dan kodak Instamatic bukan seperti foto umumnya yang menggunakan rasio 4:3.Instagram dapat diartikan menampilkan dan menyampaikan informasi berupa foto atau gambar secara cepat lewat aplikasi yang dapat diakses oleh orang lain. Tentunya, agar dapat menggunakan aplikasi Instagram, selain meng-install melalui Play Store milik Google atau Apple Store, sobat perlu terhubung terlebih dahulu dengan koneksi internet. (Kertamukti, 2015)

Instagram adalah sebuah aplikasi yang digunakan untuk membagi-bagikan foto dan video. Instagram sendiri masih merupakan bagian dari facebook yang memungkinkan teman facebook kita mem-followakun Instagram kita. Makin populernya Instagram sebagai aplikasi yang digunakan untuk membagi foto membuat banyak pengguna yang terun ke bisnis online turut mempromosikan produk-produknya lewat Instagram. (Nisrina, 2015)

Instagram merupakan salah satu media jejaring sosial yang dapat dimanfaatkan sebagai media pemasaran langsung. Melalui Instagram- lah produk barang/jasa ditawarkan dengan meng-upload foto atau video singkat, sehingga para calon konsumen dapat melihat jenis-jenis barang/jasa yang ditawarkan.

Instagram memiliki fitur-fitur yang berbeda dengan jejaring sosial lainnya, diantara sekian banyak fitur yang ada di Instagram, ada beberapa fitur yang digunakan oleh akun instagram dalam menjalanan komunikasi pemasarannya, fitur tersebut adalah:

1. Followers (Pengikut)

Sistem sosial di dalam Instagram adalah dengan menjadi pengikut akun pengguna lainnya, atau memiliki pengikut Instagram. Dengan demikian komunikasi antara sesama pengguna Instagram sendiri dapat terjalin dengan memberikan tanda suka dan juga mengomentari foto-foto yang telah diunggah oleh pengguna lainnya. Pengikut juga menjadi salah satu unsur yang penting, dimana jumlah tanda suka dari para pengikut sangat mempengaruhi apakah foto tersebut dapat menjadi sebuah foto yang populer atau tidak. Untuk menemukan teman-teman yang ada di dalam Instagram.

2. Upload Foto (Mengunggah Foto)

Kegunaan utama dari Instagram adalah sebagai tempat untuk mengunggah dan berbagi foto-foto kepada pengguna lainnya. Foto yang hendak ingin diunggah dapat diperoleh melalui kamera iDevice ataupun foto-foto yang ada di album foto di iDevice tersebut.

3. Kamera

Foto yang telah diambil melalui aplikasi Instagram dapat disimpan di dalam iDevice tersebut. Penggunaan kamera melalui Instagram juga dapat langsung menggunakan efek-efek yang ada, untuk mengatur pewarnaan dari foto yang dikehendaki oleh pengguna. Ada juga efek kamera tilt-shift yang fungsinya adalah untuk memfokuskan sebuah foto pada satu titik tertentu. Foto-foto yang akan diunggah melalui Instagram tidak terbatas atas jumlah tertentu, melainkan Instagram memiliki keterbatasan ukuran untuk foto. Ukuran yang digunakan di dalam Instagram adalah dengan rasio $3: 2$ atau hanya sebatas berbentuk kotak saja.

4. Efek Foto

Pada versi awalnya, Instagram memiliki 15 efekefek yang dapat digunakan oleh para pengguna pada saat mereka hendak menyunting sebuah foto. Efek tersebut terdiri dari: X-Pro II, Lomo-fi, Earlybird, Sutro, Toaster, Brannan, Inkwell, Walden, Hefe, Apollo, Poprockeet, Nashville, Gotham, 1977, dan Lord Kelvin. Namun tepat pada tanggal 20 September yang lalu Instagram telah menambahkan 4 buah efek terbaru yaitu; Valencia, Amaro, Rise, Hudson dan telah menghapus 3 efek, Apollo, Poprockeet, dan Gotham dari dalam fitur tersebut.

5. Judul Foto

Setelah foto tersebut disunting, maka foto akan dibawa ke halaman selanjutnya, dimana foto tersebut akan diunggah ke dalam Instagram sendiri ataupun ke jejaring sosial lainnya. Dimana di dalamnya tidak hanya ada pilihan untuk mengunggah pada jejaring sosial atau tidak, tetapi juga untuk memasukkan judul foto, dan menambahkan lokasi foto tersebut.

6. Arroba

Seperti Twitter dan juga Facebook, Instagram juga memiliki fitur yang dimana para penggunanya dapat

menyinggung pengguna lain yang juga, dengan manambahkan tanda arroba (@) dan memasukkan akun Instagram dari pengguna tersebut. Para pengguna tidak hanya dapat menyinggung pengguna lainnya di dalam judul foto, melainkan juga pada bagian komentar foto. Para pengguna 
dapat menyinggung pengguna lainnya dengan memasukkan akun Instagram dari pengguna tersebut. Pada dasarnya dalam menyinggung pengguna yang lainnya, yang dimaksudkan adalah untuk berkomunikasi dengan pengguna yang telah disinggung tersebut.

7. Geotagging

Setelah memasukkan judul foto tersebut, bagian selanjutnya adalah bagian Geotag. Bagian ini akan muncul ketika para pengguna iDevice mengaktifkan GPS mereka di dalam iDevice mereka. Dengan demikian iDevice tersebut dapat mendeteksi lokasi para pengguna Instagram tersebut berada.

8. Jejaring Sosial

Dalam berbagi foto, para pengguna juga tidak hanya dapat membaginya di dalam Instagram saja, melainkan foto tersebut dapat dibagi juga melalui jejaring sosial lainnya seperti Facebook, Twitter, Foursquare, Tumblr, dan Flickr yang tersedia di halaman Instagram untuk membagi foto tersebut.

9. Tanda suka (like)

Instagram juga memiliki sebuah fitur tanda suka yang fungsinya memiliki kesamaan dengan yang disediakan Facebook, yaitu sebagai penanda bahwa pengguna yang lain menyukai foto yang telah diunggah. Berdasarkan dengan durasi waktu dan jumlah suka pada sebuah foto di dalam Instagram, hal itulah yang menjadi faktor khusus yang mempengaruhi foto tersebut terkenal atau tidak.

10. Popular (Explore)

Bila sebuah foto masuk ke dalam halaman popular, yang merupakan tempat kumpulan dari foto-foto popular dari seluruh dunia pada saat itu. Secara tidak langsung foto tersebut akan menjadi suatu hal yang dikenal oleh masyarakat mancanegara, sehingga jumlah pengikut juga dapat bertambah lebih banyak. (Nisrina, 2015)

Dapat dipercaya bahwa instagram sangat dahsyatnya melakukan Marketing di Instagram, berikut ini merupakan beberapa faktor yang dapat dilakukan dalam marketing atau mempromosikan di instagram diantaranya:

1. Brand: tak terhitung berapa banyak jumlah brand yang besar oleh strategi pemasaran Instagram seperti Jam tangan DW (Danielle Wellington), Nike, National Geographic, Vanilla Hijab.

2. Person / Public Figure seperti artis, selebgram atau orang-orang yang memiliki follower banyak.

3. Generic Account: jenis akun selain brand dan personal dikategorikan sebagai generic account.

Beberapa yang paling popular, seperti akun berita dan informasi (jktinfo, warung jurnalis), akun lucu-lucuan (humor, gosip, kata motivasi, foto-fotoan, dari pemandangan alam, kucing-kucingan, fashion hingga makanan. Saat ini, konten tersebut mengalami pertumbuhan paling tinggi di platform Instagram), dan akun jualan.

Klasifikasi jenis account di Instagram yang seluruhnya diperbolehkan untuk kita pakai dapat menggunakan jenis apa pun yang Anda inginkan sesuai kebutuhan, misal:

1. Jika Anda memiliki produk dan merek sendiri, Anda bisa menggunakan nama Brand. Sama halnya jika itu merupakan akun IG untuk mendapatkan traffic ke blog/website Anda, maka akun brand adalah yang paling cocok.

2. Jika kebutuhannya adalah untuk popularitas personal, memajang portofolio atau juga untuk berjualan, maka Anda bisa menggunakan nama pribadi di akun Anda.

3. Jika Anda punya kebutuhan lain, maka Anda bisa menggunakan akun Generic.

Kaitannya dengan penelitian ini membahas mengenai akun instagram personal yaitu dengan menggunakan blog pribadi yang sudah memiliki popularitas dan memajang portofolio agar dapat memenuhi kebutuhan audience yang memiliki kebutuhan akan informasi yang disampaikan dalam akun@annisast yang berbagi informasi mengenai parenting.

Parenting memiliki bermacam-macam makna. Secara terminologi dapat diidentifikasikan sebagai proses mengasuh anak. Di dalam bahasa Indonesia, kata mengasuh mengandung makna metode atau cara orang tua mencukupi kebutuhan fisiologis dan psikologis anak; membesarkan anak berdasarkan standar dan kriteria yang orang tua terapkan; menanamkan dan memberlakukan tata nilai kepada anak. (Surbakti, 2012)

Selain itu, parenting memiliki arti masa menjadi orang tua (parenthood) merupakan masa yang alamiah terjadi dalam kehidupan seseorang. Namun, pada masa kini sudah sangat lazim dikenal dengan istilah parenting yang memiliki konotasi lebih aktif daripada parenthood. Istilah parenthing menggeser parenthood, sebuah kata benda yang berarti keberadaan atau tahap menjadi orang tua, menjadi kata kerja yang berarti melakukan sesuatu pada anak seolah-olah orang tualah yang membuat anak menjadi manusia. (Lestari, 2012)

Definisi lain, "parenting merujuk pada suasana kegiatan belajar mengajar yang menekankan kehangatan bukan ke arah suatu pendidikan satu arah atau tanpa emosi. (Megawangi, 2007)

Dari pengertian parenting di atas, tugas orang tua berkembang menjadi lebih dari sekedar memenuhi kebutuhan fisik, juga memberikan yang terbaik bagi kebutuhan materil anak, memenuhi kebutuhan emosi dan psikologis anak, dan menyediakan kesempatan 
untuk menempuh pendidikan yang terbaik. (Hidayati, 2010)

Program parenting merupakan kegiatan memberikan wawasan dan pengetahuan kepada orang tua tentang bagaimana menghadapi dan mengasuh anak. Orang tua dan anak menjadi perhatian penting dalam mengembangkan dan mendidik anak. Implementasi program parenting terdapat tiga tahapan yaitu, tahap perencanaan, pelaksanaan, dan evaluasi program parenting. (Sugiharto, 2014)

Perencanaan adalah suatu proyeksi (perkiraan) tentang apa yang diperlukan dalam rangka mencapai tujuan yang ditentukan. Perencanaan sering juga disebut sebagai jembatan yang menghubungkan kesenjangan atau jurang antara keadaan masa kini dan keadaan yang diharapkan terjadi pada masa yang akan datang. Dalam melakukan perencanaan yang baik dan lengkap haruslah memenuhi enam unsur pokok yaitu, apa (what), mengapa (why), bagaimana (how), dimana (where), kapan (when), siapa (who). (Sugiharto, 2014)

Pelaksanaan merupakan penerapan suatu perencanaan yang telah dirancang. Pelaksanaan bermuara pada aktivitas, aksi, tindakan atau adanya mekanisme suatu sistem, implementasi bukan sekedar aktivitas, tapi suatu kegiatan yang terencana dan untuk mencapai tujuan kegiatan. (Usman, 2002)

Berdasarkan penjelasan di atas parenting disimpulkan pola asuh dalam suatu proses interaksi total orang tua dan anak yang meliputi kegiatan seperti memelihara, memberi makan, melindungi dan mengarahkan tingkah laku anak selama masa perkembangan serta memberikan pengaruh terhadap perkembangan kepribadian anak dan terkait dengan kondisi psikologis bagaimana orang tua mengkomunikasikan afeksi (perasaan) dan norma-norma yang berlaku dimasyarakat agar anak dapat hidup selaras dengan lingkungannya.

Para ibu muda mendapatkan informasi tentang parenting atau pengasuhan anak dari orang tua, mertua, kakak ipar atau orang-orang yang dituakan lainnya. ternyata telah terjadi pergeseran dalam mendapatkan akses informasi tentang ilmu parenting dari media baru. Penyebarannya pun lebih meluas dan cepat. Dulu, akses dan akvitivas parenting sebatas dalam lingkup offline, kini bertransformasi ke ranah online. Media sosial ini menjadi salah satu alat dalam pendistribusi informasi. Bahkan, media sosial menjadi tempat untuk berbagi informasi dan pengalaman parenting di kalangan ibu muda. Salah satu media sosial yang digunakan para ibu muda ini adalah instagram. Kini sedang marak atau tren parenting Instagram dan Instamom. Memang, di era milenial ini, instagram menjadi salah satu referensi parenting. Kita bisa memperkaya pengetahuan seputar pengasuhan $\mathrm{Si}$ Kecil dari instagram. Misalnya, tentang tips pengasuhan dan menyusui, ide-ide kreatif bermain bersama anak, resep menu makanan dan camilan, bahkan kutipan-kutipan yang menginspirasi. Melalui instagram, kita dapat terhubung dengan ibu muda lainnya yang juga samasama tengah mencari informasi seputar parenting sekaligus bertukar pengalaman tentang proses parenting. (HIL, 2018)

\section{METODOLOGI PENELITIAN}

Penelitian ini membahas mengenai Pemanfaatan Blog Pribadi Di Instagram Sebagai Media Komunikasi Parenting Akun Instagram @annisast. Penelitian menggunakan pendekatan penelitian kualitatif. Metode kualitatif ini digunakan dengan tujuan untuk menjelaskan fenomena dengan sedalamdalamnya. (Kriyantono, 2007)

Jenis penelitian yang digunakan dalam penelitian ini adalah menggunkan jenis penelitian studi deskriptif kualitatif, dengan berusaha menafsirkan data-data penelitian yang berbeda. Pendekatan deskriptif bertujuan untuk menggambarkan secara detail suatu pesan atau suatu teks tertentu, metode ini hanya semata-mata untuk menggambarkan aspek-aspek dan karakteristik dari suatu pesan. (Eriyanto, 2013)

Menjelaskan objek penelitian kualitatif adalah menjelaskan objek yang menjadi fokus penelitian, yaitu apa yang menjadi sasaran penelitian. Objek penelitian ini adalah Akun Instagram @annisast”.

Jenis data yang akan digunakan dalam analisis penelitian kali ini adalah data primer dan data sekunder. Data primer didapat dari Observasi dan Dokumentasi gambar dan caption yang terdapat dalam Akun Instagram @ annisast. Sedangkan data sekunder didapat dari studi pustaka.

Teknik pengumpulan data yang digunakan dalam penelitian ini adalah Observasi data, dengan melihat isi dari uploadan baik foto dan captions, komen dari beberapa follower dalam Akun Instagram @annisast yang akan dikaji dengan cermat dan teliti. Selain itu menggunakan teknik pengumpulan data Dokumentasi isi dari Akun Instagram@annisast, gambar-gambar yang tertera.

\section{HASIL DAN PEMBAHASAN}

Penelitian ini membahas mengenai Pemanfaatan Blog Pribadi Di Instagram Sebagai Media Komunikasi Parenting Akun Instagram @annisast yang memiliki follower sebanyak $10,6 \mathrm{~K}$. Beda dengan akun lain yang berdiri atas nama bisnis atau perusahaan yang membahas parenting. Namun @annisast merupakan 
akun pribadi seorang ibu yang memiliki satu anak yang bernama Xylo berusia kurang lebih 5 (lima) tahun. Annisast merupakan seorang blogger yang fokus membahas tentang parenting di Indonesia, beliau juga sudah menghasilkan buku yang berjudul "Susahnya Jadi Ibu". Beda dengan akun parenting yang lain@annisast memberikan pengalaman sendiri yang menjadi pusat perhatian dan pengalaman seharihari yang Ia rasakan. Dalam akun instagramnya @annisast informasi, cerita, tips, solusi dan sharing dalam dan berdiskusi melalui laman komen yang membahas seputar perkembangan dan permasalahan anak, rumah tangga baik itu hubungan dengan suami dan keluarga, permasalahan dan tips dalam rumah tangga, kesehatan dan komunikasi yang baik dalam keluarga. Isi dari akun instagramnya adalah sebagai berikut:

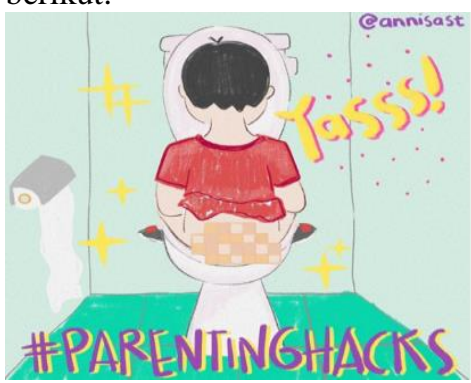

Sumber : (Annisast, 2018)

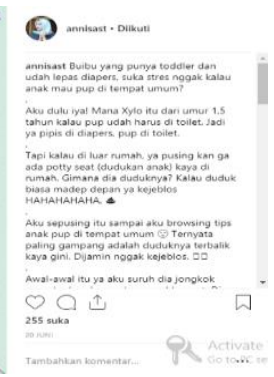

Ganbar 1. Updatean Akun Instagram @annisast

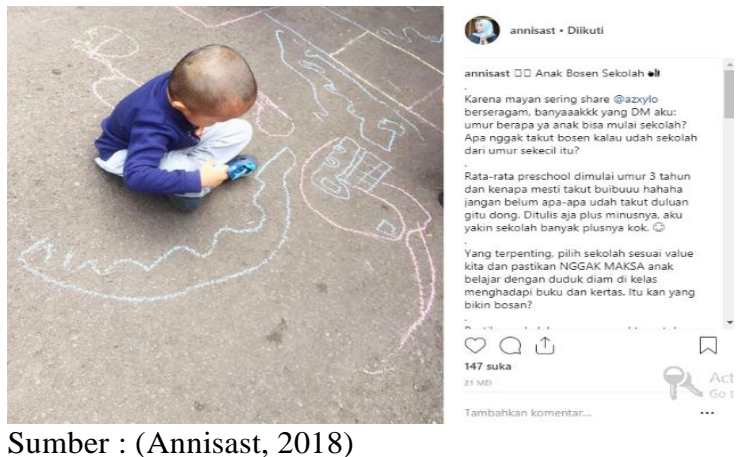

Ganbar 2. Updatean Akun Instagram @annisast

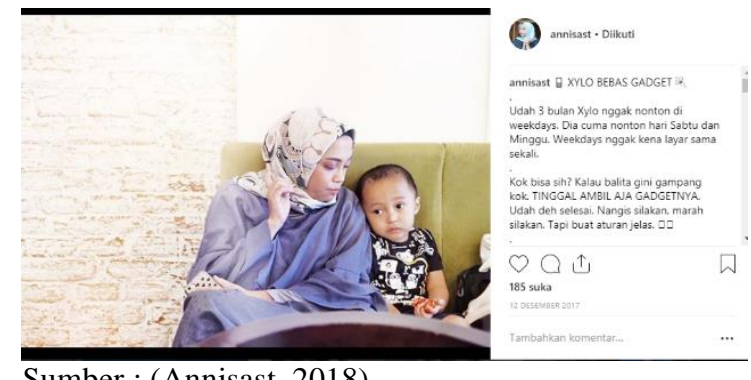

Sumber : (Annisast, 2018)

Ganbar 3. Updatean Akun Instagram @annisast

Berkaitan dengan penelitian ini Pemanfaatan Blog Pribadi Di Instagram Sebagai Media Komunikasi Parenting Akun Instagram @annisast maka
Dalam akun instagram @annisast memiliki Sistem sosial di dalam Instagram yaitu dengan menjadi pengikut akun pengguna lainnya untuk menjadi follower, @annisast memiliki follower sebanyak 10,6K. Dalam akun ini followernya sangat aktif ini terlihat dari setiap uploadannya salah satunya pada gambar 1 yang membahas tentang ParentingHacks banyak follower yang mengapresiasi seperti akun "@kartikaninggar_Mbak, thank you! Sangat mencerahkan sekali $(-) \cdot(-)$ " dan farahgeenaIni sungguh pengetahuan yg penting@pratama0815. Selain itu juga dengan adanya follower yang memberikan komentar sehingga tercipta diskusi kesesama pengguna instagram seperti yang didiskusikan oleh akun "rindacitya27Mbak@annisast, makasih bgttt udah posting yg beginian. Btw, kalo cara ngebasuhnya gimana dong?? Toilet skrg kan kebanyakan udah model yg nyemprot lgsg dr belakang gitu.. Kalo di lap tissue kering/basah aja kok kurang mantep rasanya. Mohon pencerahannya makasih". Selain memberikan komentar para follower juga memberikan tanda suka, dalam uploadan yang yang berjudul ParentingHacks ini terdapat 255 pengikut yang memberikan tanda suka.

Dari penjelasan di atas terdapat fungsi komunikasi antara yang terjadi yaitu instagram sebagai sumber media informasi dan pengetahuan parenting bagi para pemilik akun instagram.

Kegunaan utama dari Instagram adalah sebagai tempat untuk mengunggah dan berbagi foto-foto kepada pengguna lainnya sarana informasi dalam akun instagram @annisast banyak mengunggah foto-foto aktifitas pemilik akun dengan anaknya serta foto gambar yang dibuat oleh @ annisast yang berkaitan dengan isi yang dibahas contohnya pada gambar 1 foto yang berjudul parentinghack yang menggambarkan seorang anak sedang buang air besar, sesuai dengan captionnya yang membahas tentang tips mengatasi anak umur 1,5 tahun lepas diapers. @annisast memberikan pengalamannya dengan kata-kata berikut ini :

“annisastBuibu yang punya toddler dan udah lepas diapers, suka stres nggak kalau anak mau pup di tempat umum? Aku dulu iya! Mana Xylo itu dari umur 1,5 tahun kalau pup udah harus di toilet. Jadi ya pipis di diapers, pup di toilet. Tapi kalau di luar rumah, ya pusing kan ga ada potty seat (dudukan anak) kaya di rumah. Gimana dia duduknya? Kalau duduk biasa madep depan ya kejeblos HAHAHAHAHA. $\Xi$ Aku sepusing itu sampai aku browsing tips anak pup di tempat umum $\odot$ Ternyata paling gampang adalah duduknya terbalik kaya gini. Dijamin nggak kejeblos. Awalawal itu ya aku suruh dia jongkok menghadap depan dan pegel banget. Dia pegel, aku pegel 
meganginnya. Kalau duduk gini, dia enak, aku bisa main HP lol. Semoga berguna ya! Plis jangan bilang cuma aku doang yang nggak tau hahahaha \#tipsparenting ast". Dari penjelasan di atas terdapat fungsi instagram sebagai media informasi dan pengetahuan parenting bagi para pemilik akun instagram lain.

Selain itu yang sangat berperan sebagai sarana informasi dan edukasi parenting bagi follower adalah judul foto atau judul caption, yaitu adalah "Yasss...ParentingHack" yang menyatakan bahwa berhasil dalam merubah kebiasaan anak. Selain itu juga judul fotolain adalah "Anak Bosen sekolah" dengan gambar anak bain diluar rumah dijalanan yang isinya tips agar anak rajin sekolah dengan mengatakan bahwa "sekolah itu seru loh".

Penggunaan tanda arroba dalam Instagram juga memiliki fitur yang dimana para penggunanya dapat membuat pengguna lain mengetahui akun instagram kita dengan manambahkan tanda arroba (@), untuk memasukan nama akunnya @annisast nama akun anaknya @xylo dan memasukkan akun Instagram dari beberapa pengguna lain. Ini pun juga terdapat untuk beberapa follower yang menuliskan dikolom komentar, dengan tujuan para pengguna lain untuk melihat artikel yang dibuat yang dimungkinkan pengguna tersebut butuh atau dengan menyinggung kolom komentar yang membutuhkan artikel tersebut. melainkan juga pada bagian komentar foto. Para pengguna dapat menyinggung pengguna lainnya dengan memasukkan akun Instagram dari pengguna tersebut. Pada dasarnya dalam menyinggung pengguna yang lainnya, yang dimaksudkan adalah untuk berkomunikasi dengan pengguna yang telah disinggung tersebut. Penjelasan initerlihat jelas bahwa fungsi tanda addora memiliki peran dalam menginformasikan dan pembelajaran parenting bagi pengguna akun lain yang mengikuti akun @ annisast atau yang tidak mengikuti.

Selain memasukkan judul foto, dalam akun instagram @annisast sering menggunakan Geotag, yang berfungsi mendeteksi lokasi agar para pengguna instagram lain dapat mengetahui beberapa tempat yang dibutuhkan seperti sekolah, daycare, tempat bermain atau tempat revarasi mainan.

Dalam berbagi foto, dalam akun instagram @annisast juga untuk menjangkau pengguna (explore) juga tidak hanya dapat membaginya di dalam Instagram saja, melainkan foto dan tulisannya tersebut dapat dibagi juga melalui link lain seperti www.annisast.com yang merupakan blog pribadinya, selain itu juga di www.orami.co.id.
Bila sebuah foto masuk ke dalam halaman popular, yang merupakan tempat kumpulan dari foto-foto popular dari seluruh dunia pada saat itu. Secara tidak langsung foto tersebut akan menjadi suatu hal yang dikenal oleh masyarakat mancanegara, sehingga jumlah pengikut juga dapat bertambah lebih banyak. Begitu juga akun instagram @annisast untuk menjadi populer sering sekali menggunakan hastag, banyak hastag yang dituliskan salah satunya adalah \#tipsparenting.

Dari penjelasan di atas jelas akun@annisast dalam memanfaatkan penggunaan kata blog pribadi dalam instagram dapat memberikan fungsinya sebagai media komunikasi untuk memberikan informasi yang bermanfaat dan pengetahuan mengenai parenting terhadap akun lain.

\section{KESIMPULAN}

Media sosial yang semakin marak di Indonesia, dapat memudahkan penggunanya dalam melakukan komunikasi, salah satunya adalah instagram. Instagram menjadi media sosial yang cukup popular, karena setiap orang juga berlomba-lomba untuk mempopularkan dirinya dengan akun instagram dengan mencirikhaskan portofolio dan hobi baik traveler, photography, kuliner, parenting dan lainya. Salah satu akun blog pribadi di akun instragam yang @annisast merupakan salah satu parenting blogger Indonesia.

Banyak cara yang dilakukan akun instagram @annisast untuk memanfaatkan akunnya sebagai media komunikasi yang memberikan informasi dan edukasi parenting kepada pengguna akun instagram lain. Dalam akun ini followernya sangat aktif ini terlihat dari setiap uploadannya salah satunya pada gambar 1 yang membahas tentang ParentingHacks banyak follower yang mengapresiasi dengan banyak yang mengucapkan terima kasih untuk tips yang diberikan dan tercipta diskusi antara pengguna akun lain.

Selain memberikan komentar para follower juga memberikan tanda suka, dalam uploadan yang yang berjudul ParentingHacks ini terdapat 255 pengikut yang memberikan tanda suka. sarana informasi dalam akun instagram @annisast banyak mengunggah fotofoto aktifitas pemilik akun dengan anaknya serta foto gambar yang dibuat oleh @annisast yang berkaitan dengan isi yang dibahas contohnya pada gambar 1 foto yang berjudul parentinghack yang menggambarkan seorang anak sedang buang air besar, sesuai dengan captionnya yang membahas tentang tips mengatasi anak umur 1,5 tahun lepas diapers.

Selain itu yang sangat berperan sebagai sarana informasi dan edukasi parenting bagi follower adalah 
judul foto atau judul caption, yaitu adalah "Yasss...ParentingHack" yang menyatakan bahwa berhasil dalam merubah kebiasaan anak.

Penggunaan tanda arroba dalam Instagram juga untuk memasukan nama akunnya @annisast nama akun anaknya@xylodan memasukkan akun Instagram dari beberapa pengguna lain. Ini pun juga terdapat untuk beberapa follower yang menuliskan dikolom komentar, dengan tujuan para pengguna lain untuk melihat artikel yang dibuat.

Selain memasukkan judul foto, dalam akun instagram @annisast sering menggunakan Geotag, yang berfungsi mendeteksi lokasi agar para pengguna instagram lain dapat mengetahui beberapa tempat yang dibutuhkan seperti sekolah, daycare, tempat bermain atau tempat revarasi mainan. akun instagram @annisast juga untuk menjangkau pengguna juga tidak hanya dapat membaginya di dalam Instagram saja, melainkan foto dan tulisannya tersebut dapat dibagi juga melalui link lain seperti www.annisast.com yang merupakan blog pribadinya, selain itu juga di www.orami.co.id. Akun instagram @annisast untuk menjadi akun instagram populer sering sekali menggunakan hastag, banyak hastag yang dituliskan salah satunya adalah \#tipsparenting. Jadi akun instagram @annisast dalam memanfaatkan penggunaan kata blog pribadi dalam instagram dapat memberikan fungsinya sebagai media komunikasi untuk memberikan informasi yang bermanfaat dan pengetahuan mengenai parenting terhadap akun lain.

\section{REFERENSI}

Annisast. (2018). Parenting Hack. Retrieved September 16, 2018, from https://www.instagram.com/annisast/?hl=id

Bungin, B. (2007). Sosiologi Komunikasi, Teori, Paradigma, Dan Diskursus Teknologi Komunikasi Di Masyarakat. Jakarta: Kencana.

Effendy, O. U. (2001). Ilmu Komunikasi: Teori dan Praktek. Bandung: Remaja Rosdakarya.

Eriyanto. (2013). Analisis Isi Pengantar Metodologi untuk Penelitian Ilmu Komunikasi dan Ilmuilmu Sosial Lainnya. Jakarta: Kencana Perdana Media Group.

Griggs, A. (2009). Sejarah Sosial Media (Daeri Gutenberg Sampai Internet). (Y. O. Indonesia, Ed.). Jakarta.

Gunelius, S. (2011). 30-Minute Social Media Marketing. United States: McGraw-Hill Companies.

Hidayati, Z. (2010). Anak Saya Tidak Nakal. Yogyakarta: PT Bintang Pustaka.

HIL. (2018). Tren belajar parenting melalui instagram dan instamom, sejauh mana bisa diikuti? Retrieved September 16, 2018, from https://www.orami.co.id/magazine/trenbelajar-parenting-melalui-instagram-daninstamom-sejauh-mana-bisa-diikuti

Kertamukti, R. (2015). INSTAGRAM DAN PEMBENTUKAN CITRA (Studi Kualitatif Komunikasi Visual dalam Pembentukan Personal Karakter Account Instagram @ basukibtp). Jurnal Komunikasi PROFETIK, Vol. 08 No.

Kriyantono, R. (2007). Teknik Praktis Riset Komunikasi: disertai contoh riset media, public relations, komunikasi pemasaran dan organisasi (Cetakan Ke). Jakarta: Kencana Prenada Media.

Lesmana, G. N. A. (2012). Analisis Pengaruh Media Sosial Twitter Terhadap Pembentukan Brand Attachment (Studi: PT. XL AXIATA). Univeritas Indonesia.

Lestari, S. (2012). Psikologi Keluarga: Penanaman Nilai dan Penanganan Konflik dalam Keluarga. Jakarta: Prenada Media Group.

Megawangi, R. (2007). Character Parenting Space, Menjadi Orang Tua Cerdas untuk Membangkitkan Karakter Anak. Bandung: Mizan Media Utama.

Mulyana, D. (2001). Ilmu Komunikasi Suatu Pengantar. Bandung: Remaja Rosdakarya.

Nisrina, M. (2015). Bisnis Online, Manfaat Media Sosial Dalam Meraup Uang. Yogyakarta: Kobis.

Nurudin. (2013). Pengantar Komunikasi Massa. Jakarta: PT Rajagrafindo Persada.

Puntoadi, D. (2011). Menciptakan Penjualan Melalui Social Media. Jakarta: PT Elex Komputindo.

Riswandi. (2009). Ilmu komunikasi. Jakarta: Graha Ilmu.

Soehoet, H. (2003). Dasar-Dasar Jurnalistik. Jakarta:

\section{PROFIL PENULIS}

Gan Gan Giantika, S.Sos, MM adalah dosen di Universitas Bina Sarana Informatika sejak bulan September 2008. Menyelesaikan jenjang pendidikan Strata Satu (S1) di Institut Ilmu Sosial dan Ilmu Politik Jakarta (IISIP) Jakarta tahun 2002, Fakultas Ilmu Komunikasi Jurusan Hubungan Masyarakat dan sudah menyelesaikan jenjang pendidikan Strata dua (S2) Magister Manajemen pada Universitas BSI Bandung tahun 2012. Selain aktif mengajar juga aktif sebagai moderator pada acara orientasi akademik dan seminar motivasi juga aktif sebagai pembicara seminar Kapita Selekta Kewarganegaraan di Universitas Bina Sarana Infomatika. Sebelum aktif di dunia pendidikan beliau bekerja pada bidang Marketing Pemasaran pada Perusahaan swasta dan Pengajar dalam bidang teknologi komputer. 